\title{
Innovative method for optimizing the microclimate of the winter hive for bees in the conditions of the cryolithozone
}

\author{
V.K. Evsyukova*, M.S. Savvinova, V.V. Sysolyatina, F.V. Nikolaeva, and A.Ya. Fedorov \\ Federal State Budgetary Educational Institution of Higher Education "Arctic State Agrotechnological \\ University", 677007 Yakutsk, Republic of Sakha (Yakutia), Russia
}

\begin{abstract}
The article discusses the practical significance of the use of infrared scanning method for optimizing the microclimate of winter hives and monitoring bee colonies in extreme conditions of cryolithozone. When monitoring the microclimate by generally accepted zoohygienic methods, the devices record specific indicators of a particular parameter (temperature, humidity, air velocity, pressure, noise, light), while the reason for the deviation from the standard indicators for microclimate optimization is not always possible to find out. When using the infrared scanning method with the Irtis 2000SN thermal imager, it was possible to determine the reasons for the deviation of the parameters of the winter hive microclimate. The targeted elimination of defects in the enclosing structures detected by infrared scanning made it possible to quickly optimize the parameters of the winter hive microclimate. Contactless monitoring of the state of bee colonies during the winter dormancy. This early informative diagnosis without stress allows to identify a problem bee colony and take timely rescue measures. The analysis of the wintering results showed that the proportion of successful wintering in 2019 was $90 \%$, which is $20 \%$ more than in 2018 and 30\% more than in 2017 .
\end{abstract}

\section{Introduction}

Beekeeping is not a traditional branch of animal husbandry in Yakutia. In Yakutia, over the past 5 years, the following breeds (races) of honeybees have been bred: Central Russian, Carpathian, Bashkir, Far Eastern and their hybrids. Beekeeping has great development prospects in our republic. Eco-friendly northern honey today costs 2-2.5 th. rub. per $1 \mathrm{~kg}$ on the market and is in great demand among the population, but the breeding of honey bees Apis mellifera has put forward a number of problems due to the harsh natural and climatic conditions. The most difficult and decisive factor in beekeeping technology in Yakutia is the successful wintering of heat-loving insects in the extreme conditions of the cryolithozone, where the survival rate of bee colonies in the republic is less than $50 \%$.

\footnotetext{
*Corresponding author: viktoriya-snow@mail.ru
} 
Wintering in the conditions of the cryolithozone lasts on average 7 months: from the beginning of October to the middle of April, so it is difficult to overestimate the value of the optimal microclimate in the winter garden for bees in a heavy continental climate $[1,2,4]$. Creating an optimal microclimate in the wintering conditions of Yakutia is a crucial factor in the survival of bee colonies. When creating optimal indicators of microclimate parameters, the survival rate of bee colonies during the wintering period will increase, which will increase the profitability of the production of beekeeping products in the republic.

When monitoring the microclimate by generally accepted zoohygienic methods, the devices record specific indicators of a particular parameter (temperature, humidity, air velocity, pressure, noise, light), while the reason for the deviation from the standard indicators for microclimate optimization is not always possible to find out.

Monitoring of the condition of bee colonies during the wintering period should be carried out without additional noise, without turning on the light, without sharp odors and body movements, which is difficult to perform in practice without disturbing the bees.

Hypothesis: the use of an innovative infrared scanning technique can increase the proportion of successful wintering of bee colonies in the extreme conditions of Yakutia with the following solutions

1. Allow to instantly detect and visualize the defects of enclosing structures that are not detected by other devices for monitoring the parameters of the winter hive microclimate. This method allows to accurately and quickly purposefully eliminate defects, thereby allowing to create an optimal microclimate for wintering of bee colonies.

2. Allow non-contact monitoring of the state of bee colonies during the winter dormancy, when they can not be disturbed by noise, light, smell, or mechanical influences. This early diagnosis will allow to identify the problem bee colony and take timely measures.

The purpose of the research work is to determine the practical significance of using an innovative infrared scanning technique for infrared scanning to increase the survival rate of bee colonies during the winter dormancy, by optimizing the microclimate and non-contact informative monitoring of their condition.

To achieve it, the following tasks are planned:

- study of microclimate parameters by generally accepted zoohygienic methods;

- using the infrared scanning method to determine the reasons for deviation of the microclimate parameters from the standards;

- study of the state of bee colonies by infrared scanning;

- study of the results of wintering of bee colonies.

\section{Material and research methods}

The research was carried out at the apiary "Kun Tykta" in the village of Kysyr, Syr Namsky ulus in Yakutia for 3 years: 2017, 2018 and 2019.

Objects of research: parameters of the winter hive microclimate for bee colonies and bee colonies during the winter dormancy in the apiary "Kun Tykta".

The subject of the study: the parameters of the winter hive microclimate: the state of the enclosing structures of the winter hive, air temperature, humidity, air movement, noise level, atmospheric air pressure, illumination, carbon dioxide concentration and the physiological state of bee colonies during the winter dormancy. 
Generally accepted zootechnical and zoohygienic methods of research were used with the use of the following devices: thermometers, hygrometers, cup aneroid, barometer, lux meter with selenium indicator, anemometers.

The modern devices meteometer MES-200A and thermal imager (thermograph) Irtis $2000 \mathrm{SN}$ were used

Meteometer MES-200A (certificate of verification No. 0059575 of the Federal State Institution "Test-S.-Petersburg") was used to measure pressure, relative humidity, temperature, air velocity, as well as harmful gases: carbon monoxide, hydrogen sulfide, sulfur dioxide (II). The data obtained from the device were compared with the results of conventional measurements.

To detect defects in the enclosing structures and monitor the condition of the bee colonies, a thermal imager (thermograph) Irtis 2000", working on the infrared spectrum, was taken.

The programs IR Preview for visualization and digital analysis of thermograms obtained in the infrared spectrum and Decibel Reader for determining the noise level were used.

Irtis-2000 SN is a precision optical-mechanical scanning infrared device for visualization and measurement of thermal fields. The IRTIS $2000 \mathrm{SN}$ thermograph is included in the State Register and is a measuring instrument (number in the GRSI RF: 565/8-14).

The sensitivity of the specified model at $30^{\circ} \mathrm{C}$ is $3-5(8-12)$ microns. Operating temperatures from $-40^{\circ} \mathrm{C}$ to $+200^{\circ} \mathrm{C}\left(+1700^{\circ} \mathrm{C}\right)$ In thermographic studies in veterinary medicine, the speed of scanning is of particular importance, since it is difficult to achieve long-term immobility of the animal. The frame scan time is $1.5(0.6)$ seconds. Measurement accuracy \pm is $1 \%$ or $\pm 1^{\circ} \mathrm{C}$. The range of clear focus distances is $30 \mathrm{~cm}$ or more (see Table $1)$.

Table 1. Technical characteristics of the Irtis $2000 \mathrm{SN}$ thermal imager

\begin{tabular}{|l|l|c|}
\hline 1. & Infrared receiver & $\mathrm{InSb}(\mathrm{HgCdTe})$ \\
\hline 2. & Sensitivity at $30^{\circ} \mathrm{C}$ & $3-5(8-12)$ microns \\
\hline 3. & Measuring range & $0,05^{\circ} \mathrm{C}$ \\
\hline 4. & Measurement accuracy & $\pm 1 \%$ or $\pm 1{ }^{\circ} \mathrm{C}$ \\
\hline 5. & Operating temperatures & $-50^{\circ} \mathrm{C}-+200^{\circ} \mathrm{C}\left(+1700^{\circ} \mathrm{C}\right)$ \\
\hline 6. & Spatial resolution & Max 2 millirad \\
\hline 7. & Camera field of view & $25 \mathrm{X} 20$ deg. \\
\hline 8. & Frame resolution & $256(512) \mathrm{X} 256$ \\
\hline 9. & Frame scan time & $1.5(0.6)$ sec. \\
\hline
\end{tabular}

Information about the temperature distribution on the body surface is visualized on the thermal imager screen in the form of a color scan. (different colors) correspond to different temperatures.

Based on the results of thermal imaging, the information obtained is analyzed and processed, and a report is compiled indicating all the identified defects in the enclosing structures with an illustration of images in the visible and infrared range [5].

The Irtis 2000SN thermal imager can work up to a temperature of $-50^{\circ} \mathrm{C}$, which is suitable for research in our region. Fog and precipitation interfere with the operation of the device. In order to avoid distortion of the measurement results, the studies were carried out in the absence of fog, precipitation and winds, at an outdoor air temperature of $-48^{\circ} \mathrm{C}$.

In addition to the above methods, the following methods were used: observation, photography, and statistical method. 
Scientific novelty: for the first time in the conditions of Yakutia, an infrared scanning technique was used to increase the survival rate of bee colonies during the winter dormancy, by optimizing the microclimate and non-contact informative monitoring of the state of bee colonies.

Practical significance: a positive result was obtained in practice - the share of successful wintering at the Kun Tykta bee farm in 2019 was $90 \%$, which is $20 \%$ more than in 2018 and $30 \%$ more than in 2017 (Table 2).

\section{Research results}

The average humidity in the winter hive is $42 \%$, which does not correspond to the zoohygenic norm (Fig. 1). The optimal humidity should be $75-85 \%$, but not lower than $65 \%$. In the inter-frame space, the air humidity is $43 \%$, which is also lower than the zoohygienic norm (Fig. 2). The humidity was optimized by placing water vessels in 3 places on the floor.

According to the results of the measurement by the meteorological meter device "MES 200A", the pressure reached $750 \mathrm{Hg}(100 \mathrm{kPa})$, which is within the zoohygienic norm.

The illumination is measured by a light meter with a selenium indicator. In the winter hive, the illumination is 0.0003 Lux, which corresponds to the zoohygienic requirements for winter hives.

The noise level in the winter hive was measured by the Decibel Reader program. This analysis is comparative, because it is not measured by a noise meter. The measurement was carried out after 30 minutes, when the bees calmed down. An external Sony microphone was connected to an Acer laptop and the Decibel Reader program was launched. The average noise level in the winter hive is $9 \mathrm{DB}$, which corresponds to the zoohygienic norm.

The average air temperature was $+5^{\circ} \mathrm{C}$, but in some places negative indicators of $-18^{\circ} \mathrm{C}$ were observed. The range of temperature fields turned out to be wide. The speed of air movement in the winter hive premise is $0.18 \mathrm{~m} / \mathrm{s}$ in some places (Fig. 3), which exceeds the zoohygienic standard by $0.08 \mathrm{~m} / \mathrm{s}$ and $0.30 \mathrm{~m} / \mathrm{s}$ (Fig.1,2,3,4 and Table 2).

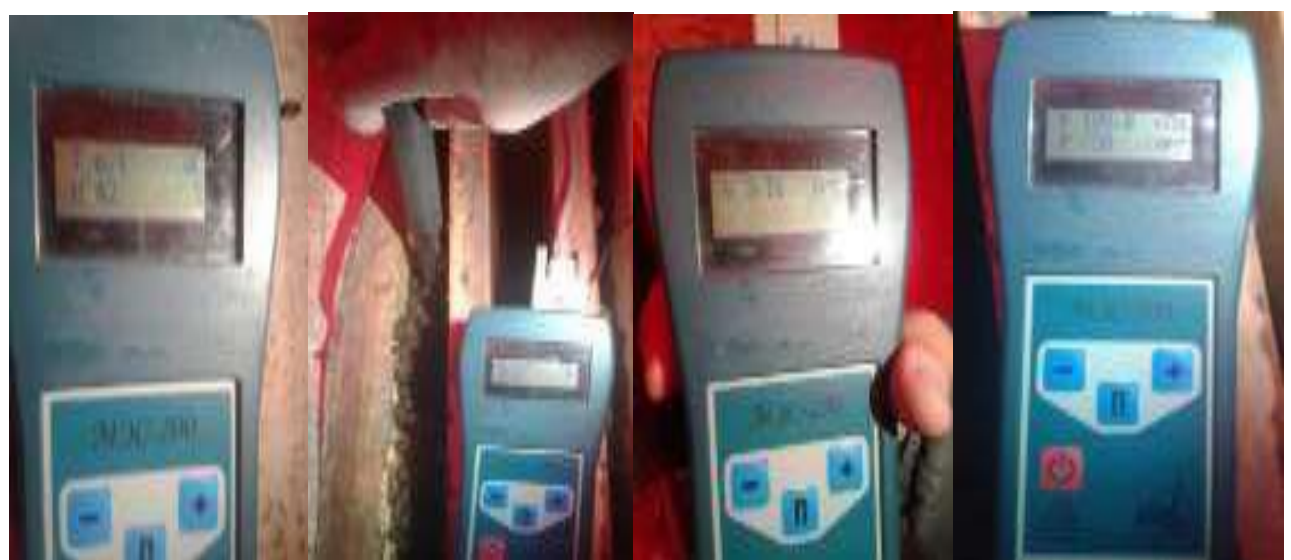

Fig. 1. Indicator of temperature and humidity
Fig. 2. Measurements in the hive inter-frame space
Fig. 3. Air velocity

Fig. 4. Pressure measurement 
The reason for deviations from the zoohygienic norm was determined during the study in the infrared spectrum with the Irtis 2000SN thermal imager.

During the thermal imaging control of the external enclosing structures of the building, it was found that the temperature field is uneven. Defective areas with low thermal characteristics were identified on the enclosing structures. Such areas are: the seams of inter-panel insulation joints (glass wool) and the internal chipboard panels. In some places, the sealing of the joints of the enclosing structures (floor, walls, floorboards) was carried out poorly or damaged during operation (Table 2 and Figure 5,6,7,8,12).

The optimization of the in-nest microclimate is to ensure that the temperature, gas composition and humidity of the air are at the levels at which the bees spend the minimum amount of energy on vital activity processes [3]

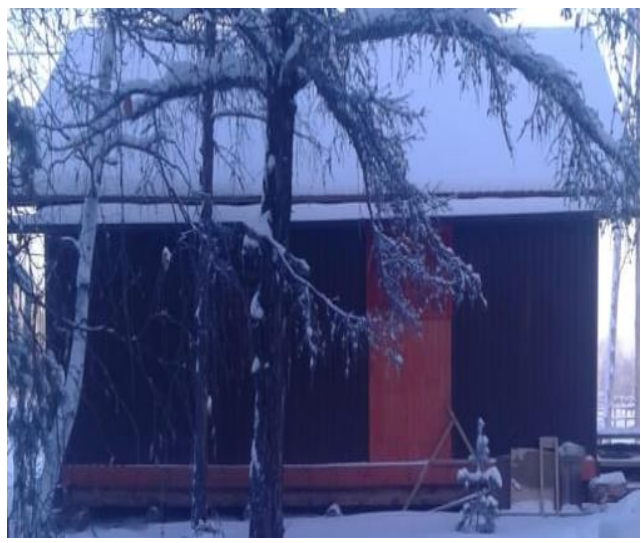

Fig. 5. View of the winter hive from the left side.

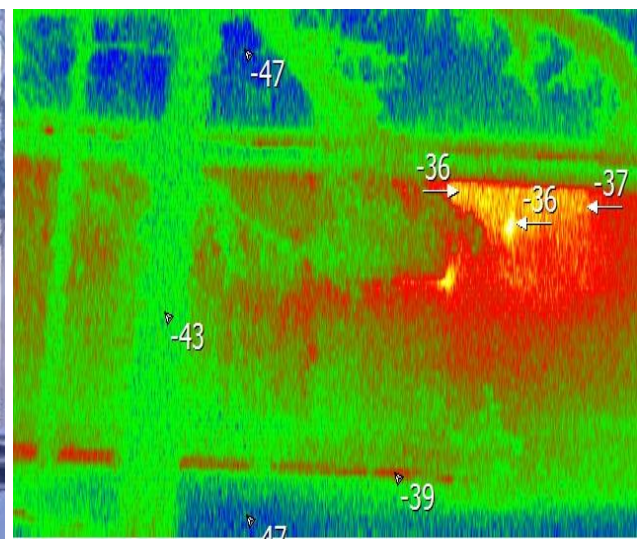

Fig. 6. Heat chart with defects of winter hive enclosing structures.

Table 2. Microclimate parameters of the winter hive for bee colonies at an outdoor temperature of $-48^{\circ} \mathrm{C}$

\begin{tabular}{|c|c|c|}
\hline Microclimate parameters & $\begin{array}{c}\text { Zoohygienic } \\
\text { standard for the } \\
\text { winter hive for bees }\end{array}$ & $\begin{array}{c}\text { Indicators of winter hive parameters } \\
\text { "Kun Tykta" }\end{array}$ \\
\hline $\begin{array}{l}\text { Average air temperature at the level } \\
\text { of } 3 \text { points }\left({ }^{\circ} \mathrm{C}\right)\end{array}$ & $-4^{\circ} \mathrm{C}$ to $+4^{\circ} \mathrm{C}$ & $5 \pm 2,15^{\circ} \mathrm{C}$ \\
\hline Air humidity (\%) & $75-85 \%$ & $42 \%$ \\
\hline $\begin{array}{l}\text { Air humidity (\%) in the inter-frame } \\
\text { space }\end{array}$ & $\min 60-65 \%$ & $43 \%$ \\
\hline Air velocity $(\mathrm{m} / \mathrm{s})$ & $0.10 \mathrm{~m} / \mathrm{s}$ & $0.18-0.40 \mathrm{~m} / \mathrm{s}$ \\
\hline Illumination (lux) & 0.0003 Lux & $0.0003 \pm 0.0001 \mathrm{Lux}$ \\
\hline Atmospheric air pressure $\mathrm{Hg}$ & $750-760 \mathrm{Hg}$ & $750 \pm 1 \mathrm{Hg}$ \\
\hline $\begin{array}{l}\text { Joints of walls and floors during } \\
\text { thermal imaging }\end{array}$ & Without defects & $\begin{array}{l}\text { Defects with a temperature of } 21^{\circ} \mathrm{C} \\
\text { were detected }\end{array}$ \\
\hline $\begin{array}{l}\text { Joints of floorboards during thermal } \\
\text { imaging }\end{array}$ & Without defects & $\begin{array}{l}\text { Defects with a temperature of } 21^{\circ} \mathrm{C} \\
\text { were detected }\end{array}$ \\
\hline Entrance group & Without defects & $\begin{array}{l}\text { Defects with heat leakage were } \\
\text { detected, } \\
\text { heating outdoor air up to } 36^{\circ} \mathrm{C} \text { at an } \\
\text { outdoor temperature of }-48^{\circ} \mathrm{C}\end{array}$ \\
\hline
\end{tabular}

The entrance group (doors) have shutter defects, which leads to insignificant, but noticeable heat losses from above (Table 2 and Fig. 5,6). Heat loss can be minimized by 
better sealing. Heat losses were detected through the joints of external structures in contact with the floor (Fig. 7,8,12), as well as between the joints of the floorboards (Fig.8).

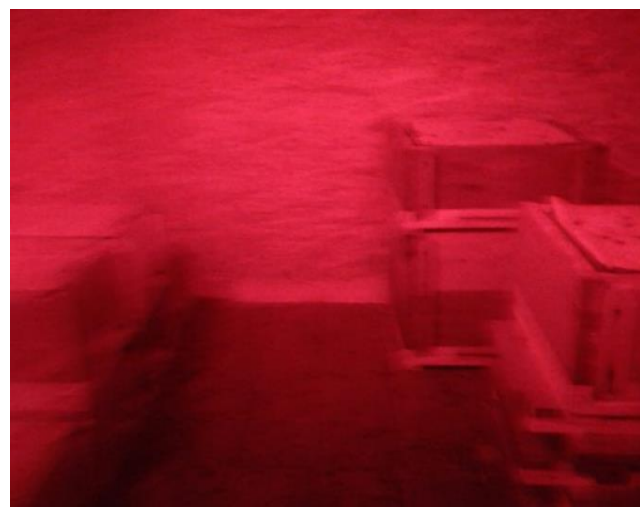

Fig. 7. Floor and walls of the winter hive back wall.

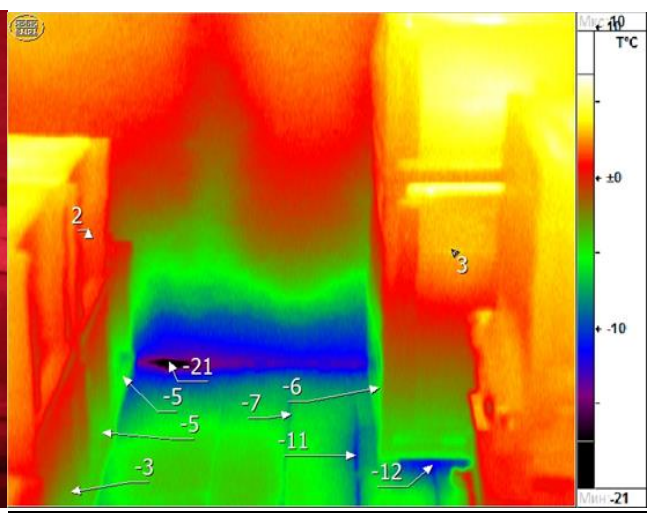

Fig. 8. Heat chart with defects of winter hive enclosing structures of joints of walls, floors and floorboards with a temperature of $-21^{\circ} \mathrm{C}$.

To eliminate heat losses, measures were taken to insulate the joints between the panels, the upper part of the door, the walls and floor, floorboards.

The use of the infrared scanning method made it possible to instantly determine the reasons for deviations from the standards of the winter hive microclimate parameters for bees (Fig. 6,8,12), thereby promptly and purposefully eliminate them, and optimize the parameters of the winter hive microclimate (Table.2), and increase the successful wintering of bees (Table 2).

When using the infrared scanning method in 2019, the reasons for deviations from the zoohygienic standards were identified in a timely manner and purposefully eliminated, thereby creating an optimal microclimate for wintering of bees (Table 2).

When monitoring the condition of bee colonies, the beekeeper should not disturb or irritate the bees with any noise, light, smell, or mechanical action, which irritates and reduces their winter hardiness.

The following informative data was obtained:

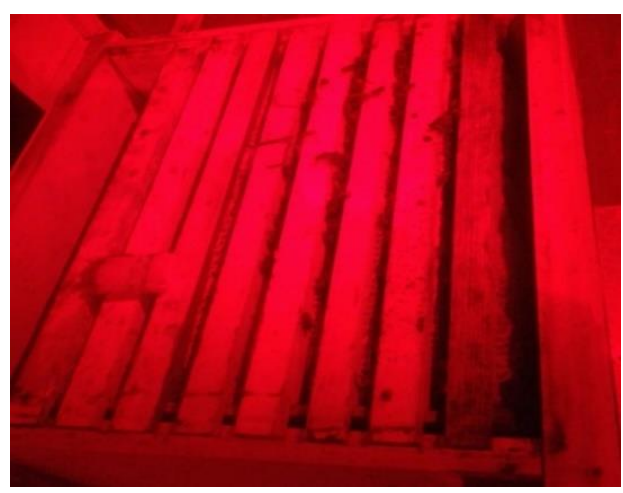

Fig. 9. Photo of the overframe space.

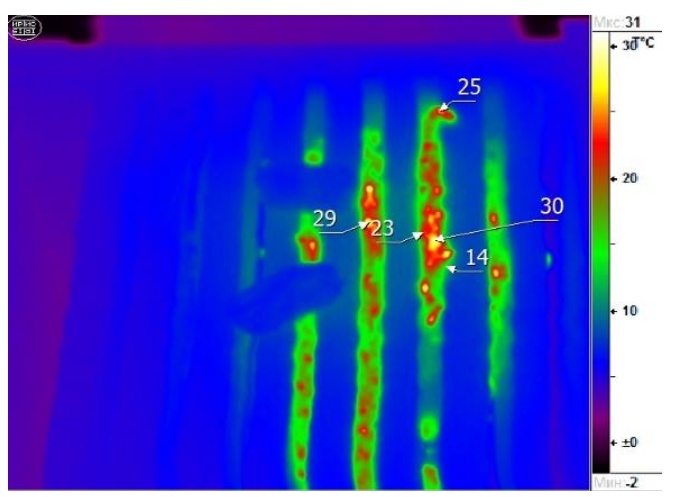

Fig. 10. Thermal diagram of the temperature distribution in overframe space with the analysis of thermal fields. 


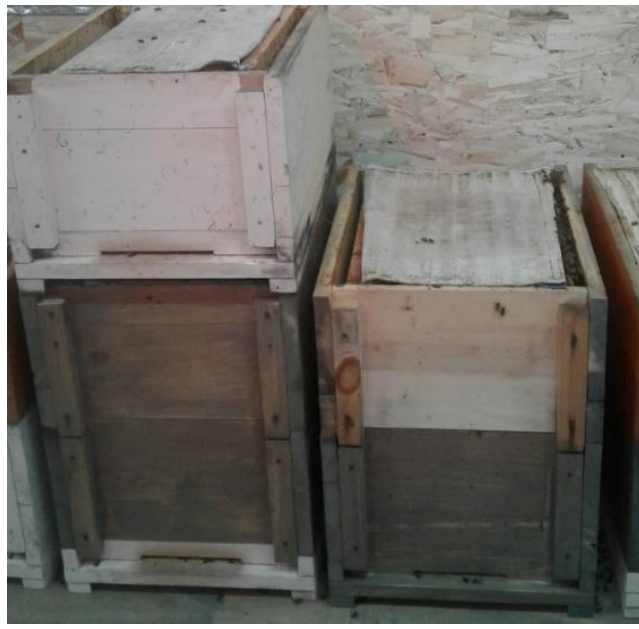

Fig. 11. Defects and club placement are not visible in the photo.

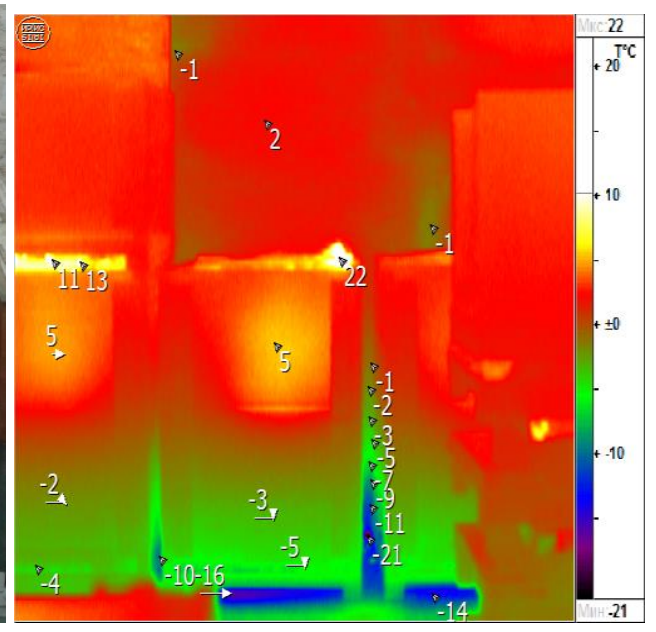

Fig. 12. Heat chart shows the club placement and the defects of the walls and ceiling with temperatures.

As can be seen from the thermal diagram (Fig.10), the main core (thermal center) of the club is located on 2-3 frames. The club density is not destroyed, the bees are calm. The club center temperature is $30^{\circ} \mathrm{C}$, which proves the absence of brood (the presence of brood in the winter months is extremely undesirable - the food reserves and resources of the bee body are depleted, which would lead to colony death). In the presence of brood, the club temperature rises to $36.5^{\circ} \mathrm{C}$ ).

The club is located on the 2nd unit (Fig. 11, 12). The placement of the bee club on the second unit is explained by the low temperatures of defects in the joints of the walls and floor, as well as between the floor boards (Fig.3,4,7,8). By the nature of the bee colony, the club rushes to the warmest place, even if there are feeding frames on the first one. Cold and draughts irritate bees (Fig. 12).

The use of a thermal imager made it possible to perform non-contact monitoring, without disturbing the bees, and to obtain visual informative material.

Knowing about the state of the bee colony in winter will help beekeepers to optimize the wintering conditions and prevent the possibility of its death [7].

Thermal imaging provides an opportunity to receive information remotely quickly and easily, monitor the state of bee colonies with absolute harmlessness for them, contributes to solving a number of diagnostic problems of practical beekeeping, and allows to make a long-term work plan with each colony [6].

When using the infrared scanning method in 2019, the reasons for deviations from the zoohygienic standards were identified in a timely manner and purposefully eliminated, thereby creating an optimal microclimate for wintering of bees (Table 3).

Table 3. Results of wintering of bee colonies in the apiary "Kun Tykta".

\begin{tabular}{|c|c|c|c|}
\hline \multirow{2}{*}{ Indicators } & \multicolumn{3}{|c|}{ Years studied } \\
\cline { 2 - 4 } & 2017 & 2018 & 2019 \\
\hline Number of bee colonies before wintering (pcs) & 60 & 40 & 40 \\
\hline Number of bee colonies after wintering (pcs) & 36 & 28 & 36 \\
\hline
\end{tabular}




\begin{tabular}{|l|l|l|l|}
\hline Specific weight of successful wintering (\%) & 60 & 70 & 90 \\
\hline
\end{tabular}

The analysis of the wintering results showed that the proportion of successful wintering in 2019 was $90 \%$, which is $20 \%$ more than in 2018 and $30 \%$ more than in 2017 (Table 3).

\section{Conclusions}

1. When studying the microclimate parameters of the winter hive by generally accepted zoohygenic methods, the following results were obtained: there is a strong range of temperature fields, the average air temperature is $5 \pm 2.15^{\circ} \mathrm{C}$, which is higher than the standard by $+1^{\circ} \mathrm{C}$, in some places the temperature decreases to $-18^{\circ} \mathrm{C}$; air humidity is only $42 \%$, which is lower than the standard by $33-43 \%$; air humidity in the inter-frame space is $43 \%$, which is lower than the standard by $17-22 \%$; air velocity is $0.18-0.40 \mathrm{~m} / \mathrm{s}$, which is higher than the standard by $0.08-0.3 \mathrm{~m} / \mathrm{s}$; illumination 0.0003 Lux meets the requirements of zoological hygiene; atmospheric air pressure is $750 \pm 1 \mathrm{Hg}$. - within the normal range (Fig. 1,2,3,4).

2. When studying using infrared scanning technology (method) with the thermal imager Irtis $2000 \mathrm{SN}$ to determine the reasons for the deviation of the microclimate parameters from the standards, the following results were obtained: defects of enclosing structures were found: joints of walls and floors and joints of floor boards with a minus temperature of up to $-21^{\circ} \mathrm{C}$; the entrance group with a defect of heat leakage, warming the outdoor air to $-36^{\circ} \mathrm{C}$ at an outdoor temperature of $-48^{\circ} \mathrm{C}$; the reason for the deviation of the air velocity of $0.18-0.40 \mathrm{~m} / \mathrm{s}$ deviation from the standard by $0.08-0.30 \mathrm{~m} / \mathrm{s}$ are the defects of the enclosing structures (Fig. 5,6,7,8,12).

3. Infrared scanning can successfully monitor the state of bee colonies, without disturbing them at the time of winter dormancy: the heat charts clearly visualize where the club of bees sits, what frames it occupies, whether there is a brood at the club temperature (Fig. 11,12).

4. The analysis of the wintering results showed that the proportion of successful wintering in 2019 was $90 \%$, which is $20 \%$ more than in 2018 and $30 \%$ more than in 2017 (Table 3).

The innovative method of infrared scanning with a thermal imager (thermograph) Irtis $2000 \mathrm{SN}$ allows to increase the success rate of wintering of bee colonies up to $90 \%$ in the beekeeping sector due to the following factors:

1.Instant detection and visualization of the defects of enclosing structures that are not detected by other devices for monitoring the parameters of the winter hive microclimate. This method allows to accurately and quickly purposefully eliminate defects, thereby to create an optimal microclimate for wintering of bee colonies in extreme conditions of the cryolithozone.

2. Contactless monitoring of the state of bee colonies during the winter dormancy. This early diagnosis allows to identify the problem bee colony and take timely measures to save the bee colony by the beekeeper.

\section{References}

1. N.L. Burenin, G.N. Kotova, Beekeeping, 461 (Moscow, Kolos, 1994)

2. V.K. Evsyukova, M.S. Savvinova, P.S. Fedotov, Mag. Beekeeping, 3, 14-17 (2018) 
3. E.K. Eskov, Wintering of bee colonies, 16 (Novosibirsk, RIPEL, 1992)

4. R.B. Kozin, N.I. Krivtsov, V.I. Lebedev, V.M. Maslennikova, Beekeeping, (Saint Petersburg, Lan, 2010)

5. N.L. Mikhailova, N.S. Chernitsov, D.A. Logval, A.A. Trofimova, E.V. Shishkov, Mag. Actual problems of humanities and natural sciences, 1-2, 110-112 (2016)

6. V.A. Toboev, Mag. Beekeeping, 10, 14-16 (2005)

7. N.M. Maximov, E.V. Losyakova, Mag. Proceedings of the Velikiye Luki State Agricultural Academy, 2, 8-12 (2017) 